\title{
新設コンクリート部材における水分特性と表層透気性に関する研究 RELATIONSHIP BETWEEN SURFACE AIR PERMEABILITY AND MOISTURE BEHAVIOR OF NEWLY CONSTRUCTED CONCRETE MEMBERS
}

\author{
田中章夫 ${ }^{* 1}$, 今本啓一 ${ }^{* 2}$, 清原千鶴 ${ }^{* 3}$ \\ Akio TANAKA, Kei-ichi IMAMOTO and Chizuru KIYOHARA
}

\begin{abstract}
The air permeability of the surface layer of concrete made from ordinary Portland cement, Portland blast furnace cement type B, and fly ash cement cast indoors and outdoors, was measured by the Wenner method and ceramic sensors. The effects of the water content in concrete at 1 year after casting on surface-layer air permeability were examined to evaluate the durability of newly built structures with surface-layer air permeability. The results indicate that the water content of concrete affects air permeability, but that it may be possible to conduct outdoor evaluations similar to those performed in a stable indoor environment by gauging the environmental conditions of a structure appropriately and adding Wenner method resistivity.
\end{abstract}

Keywords : Coefficient of Air Permeability, D ouble-chamber M ethod, Non-destructive, M oisture behavior 透気係数, ダブルチャンバー法, 非破壊, 水分挙動

\section{1. はじめに}

現在日本国内では, 持続可能な社会に向けて, グリーン購入法を 一環とした産業副産物の積極利用や, インフラの長寿命化が推進さ れている。老朽化したインフラ構造物は, 耐久性診断を行い適切な 補修・補強を実施していくこととなるが，適切な事前対策や管理を 実施する予防保全も必要とされている。限られた社会資本, 環境問 題及び人口減少問題の観点からも, 点検による健全度評価, 長寿命 化改修ならびに高い耐久性を担保した施工方法による新設構造物の 建設を推進し, 効率的に管理しなければならない。すなわち, 現在, 我々が持ちうる資本に対し, 構造物の耐久性, 劣化の程度及び建設 から更新に掛かるコストを踏まえた包括的なマネジメントを行い, 構造物の適切な保全管理を行うためには, 様々な施工プロセスや環 境・社会的ニーズを考慮した維持管理計画を含めた総合評価が重要 となる。それを実現するためには, 既存コンクリート構造物の耐久 性評価だけではなく, 高耐久性化した鉄筋コンクリート構造物の施 工時耐久性評価技術の策定が必要と考えられる。

鉄筋コンクリート構造物の耐久性能は, 一般に鉄筋の腐食度合い で定義されるが，鉄筋を腐食せしめる因子は，コンクリート内部に 有害物質が無い限りかぶり部分のコンクリートを通して外部より浸 入する。複数の施工工程を経た鉄筋コンクリート構造物において, 材料の性能そのものが耐久的であることは構造物の耐久性能を満足 寸るための必要条件ではあるが,十分条件とは成り得ない。打込み, 締固め及び養生などの複数の施工プロセスが構造物の耐久性能を大
きく左右する鉄筋コンクリート構造物は原位置で評価することが重 要である。かぶりコンクリートの, 例えば透気性といった粗密の評 価は，この意味で鉄筋コンクリート構造物の直接的な耐久性評価に つながるものであると考える。一方，コンクリート中の水分は透気 性に大きく影響するため, 特に新設構造物においては, 試験時にお ける水分評価が重要である。新設コンクリートを対象とした材齢と 透気性の関係については蔵重ら ${ }^{1)}$ にって検討がなされており, 試 験時における透気係数と屋内湿度環境の関係は M. Rommer ${ }^{2}$ によって 検討されている。また，スイスでは Swiss standard SIA 262:2003 として, 試験時の含水状態が $5.5 \%$ 以下を満たす環境において測定と 定められている ${ }^{3)}$ 。しかし, 若材齢コンクリート中の水分挙動と表 層透気性の関係を定量的に検討した研究は必ずしも多くない。

そこで本研究では, 新設コンクリート構造物の耐久性評価方法を 確立することを目的とし，透気性に影響を与えるコンクリート中の 水分挙動を把握し，その透気性との関係について検討した。異なる 環境下（屋外・屋内）における評価は，コンクリート表層部の水分 状態をコンクリート表面から測定する「四電極法電気抵抗計 (Wenner 法)」及び「電気抵抗式含水率計」を用いて評価した。また, 内部水 分状態の評価は, 湯浅ら ${ }^{4)}$ によて開発された「セラミックセンサ を用いた埋込み式含水率測定方法」によって試みた。透気性の評価 はダブルチャンバー法 ${ }^{5)}$ （以下，TPT 法）を用いて評価し，水銀圧 入法による細孔構造解析を実施し, 透気係数に影響を与える内在水 分と細孔構造の関係について複合的な検討を行った。
*1 (株)八洋コンサルタント技術センター 工修

*2 東京理科大学工学部建築学科 教授. 博士 (工学)

*3 東京理科大学工学部建築学科 補手·博士 (工学)
Hachiyo Consultant Corporation, Technical Center, M.Eng.

Prof., Faculty of Engineering, Tokyo University of Science, Dr.Eng.

Research Assistant, Faculty of Engineering, Tokyo University of Science, Dr.Eng. 
表 1 コンクリートの調合と諸性状

\begin{tabular}{|c|c|c|c|c|c|c|c|c|c|c|c|c|c|c|}
\hline \multirow{2}{*}{ 記号 } & \multirow{2}{*}{$\begin{array}{l}\text { W/B } \\
(\%) \\
\end{array}$} & \multirow{2}{*}{$\mathrm{s} / \mathrm{a}$} & \multicolumn{9}{|c|}{ 単位量 $\left(\mathrm{kg} / \mathrm{m}^{3}\right)$} & \multicolumn{2}{|c|}{ フレッシュ性状 } & \multirow{2}{*}{$\begin{array}{c}\text { 圧縮強度 } \\
\left(\mathrm{N} / \mathrm{mm}^{2}\right) \\
\end{array}$} \\
\hline & & & W & $\mathrm{C}$ & $\mathrm{FA}$ & $\mathrm{S} 1$ & $\mathrm{~S} 2$ & S3 & G1 & $\mathrm{G} 2$ & $\operatorname{Ad}(\mathrm{C} \times \%)$ & $\mathrm{SL}(\mathrm{cm})$ & Air $(\%)$ & \\
\hline $21-18-20 \mathrm{~N}$ & 61.0 & 48.4 & 182 & 298 & - & 427 & 171 & 255 & 459 & 471 & 1.1 & 18 & 5.3 & 32.0 \\
\hline $21-18-20 \mathrm{BB}$ & 61.5 & 48.3 & 181 & 294 & - & 425 & 171 & 255 & 459 & 471 & 1.1 & 18 & 5.2 & 36.6 \\
\hline $\mathrm{FB}$ & 57.0 & 47.8 & 170 & 238.4 & 59.3 & 421 & 173 & 255 & 465 & 477 & 1.1 & 20.5 & 4.1 & 35.5 \\
\hline
\end{tabular}

※圧縮強度は標準水中養生とし，21-18-20N 及び21-18-20BB は材齢 28 日，FB は材齢 91 日の結果である。

\section{表 2 使用材料}

\begin{tabular}{|c|c|}
\hline 水 $(W)$ & 上澄水 $(\mathrm{FB} の$ の上水道水 $)$ \\
\hline セメント (C) & $\begin{array}{l}\text { 普通ポルトランドセメント 密度 } 3.15 \mathrm{~g} / \mathrm{cm}^{3} \\
\text { 高炉セメント B 種 密度 } 2.91 \mathrm{~g} / \mathrm{cm}^{3}\end{array}$ \\
\hline 混和材（FA） & フライアッシュ \\
\hline 細骨材（S1） & 砕砂 表乾密度 $2.58 \mathrm{~g} / \mathrm{cm}^{3}$, 吸水率 $2.87 \%$ \\
\hline 細骨材（S2） & 石灰砕砂 表乾密度 $2.67 \mathrm{~g} / \mathrm{cm}^{3}$, 吸水率 $0.89 \%$ \\
\hline 細骨材（S3） & 山砂 表乾密度 $2.60 \mathrm{~g} / \mathrm{cm}^{3}$, 吸水率 $1.23 \%$ \\
\hline 粗骨材（G1） & 砕石 表乾密度 $2.61 \mathrm{~g} / \mathrm{cm}^{3}$, 吸水率 $2.76 \%$ \\
\hline 粗骨材（G2） & 石灰砕石 表乾密度 $2.69 \mathrm{~g} / \mathrm{cm}^{3}$, 吸水率 $0.65 \%$ \\
\hline 混和剤（Ad） & ポリカルボン酸系 AE 減水剂 \\
\hline
\end{tabular}

\section{2. 試験概要}

\section{1.コンクリートの使用材料及び調合}

本研究に使用したコンクリート調合及び諸性状を表 1 , 使用材料 を表 2 に示す。本研究では，21-18-20N の普通コンクリートを基準 とし, 土木構造物で多く使用されている高炉セメント B 種を用いた コンクリート（以下，21-18-20BB）及びフライアッシュ B 種を用い たコンクリート (以下，FB）の 3 種類を用いた。21-18-20N 及び 21-18-20BB はプラントにて実機練によるコンクリートとし, ポンプ 圧送により打設を行った。また，FB は 100L 強制 2 軸ミキサを用い て練混ぜを行い，手投入により打設を行った。

\section{2. 試験体水準}

試験体水準を表 3 に示す。試験体は，コンクリート中の水分挙動 と透気性の関係を検討するため, 屋外 (雨掛あり, 写真 1), 屋内 (恒 温恒湿室 $20^{\circ} \mathrm{C}$, Rh $60 \%$ ) の異なる環境下に静置した。

屋外環境下には，W $120 \times H \quad 90 \times D 20$ cm（D10 ダブル@200mm） の模擬壁試験体を静置し, 南西方向を測定面とした. 屋内環境下で は，模擬壁と単位長さあたりの保持水分条件を同一にするため, 試 験体厚さを同一にしたW $20 \times \mathrm{H} 20 \times \mathrm{D} 20 \mathrm{~cm}$ の形状を有する小型試 験体と，細孔構造解析を実施するためW $10 \times \mathrm{H} 10 \times \mathrm{D} 40 \mathrm{~cm}$ の管理 試験体を静置した。全ての試験体は材齢 7 日で脱型し, 直ちに測定 面を除く 4 面についてアルミテープを用いて封縅処理を実施した。

なお，以降の考察において，気象観測デー夕は国土交通省気象庁 によるものを採用した ${ }^{6}$ 。また, 乾燥日数とは, 脱型材齢 7 日を基 準としたものである
表 3 試験体水準

\begin{tabular}{|c|c|c|c|}
\hline 試験体名 & 模擬壁試験体 & 小型試験体 & 管理試験体 \\
\hline 形状 & W1200 $\times$ H900 $\times$ D200 & $\square 200 \times 200$ & $100 \times 100 \times 400$ \\
\hline 鉄筋 & D13@200 ダブル & 無筋 & 無筋 \\
\hline 周辺環境 & $\begin{array}{c}\text { 屋外（雨掛かり有） } \\
\text { 測定面：西面 }\end{array}$ & \multicolumn{2}{|c|}{ 屋内 $\left(20^{\circ} \mathrm{CRh} 60 \%\right)$} \\
\hline 脱型材齢 & \multicolumn{3}{|c|}{ 材齢 7 日 } \\
\hline CS-深さ & $1,3,5$ & & - \\
\hline 試験項目 & $\begin{array}{r}\text { TPT 法, Wenn } \\
\text { 電気抵抗式含水率, }\end{array}$ & $\begin{array}{l}\text { r 法, } \\
\text { 内部電気抵抗 }\end{array}$ & $\begin{array}{l}\text { 水銀圧入法 } \\
\text { 細孔構造解析 }\end{array}$ \\
\hline
\end{tabular}

\section{3. 試験方法}

\section{(1) 含水状態の試験方法}

\section{(1)セラミックセンサを用いた埋込み式水分測定方法}

試験体形状，セラミックセンサ埋設方法および測定位置を図 1 に 示す。セラミックセンサの作製はセラミック端面に金ペーストの蒸 着を行った後, 導電性接着剤（熱硬化型 1 液性エポキシ，導電性物 質として銀フィラー）を用いて銅線を接着した。接着した端子部に エポキシ樹脂による絶縁処理を実施し，これをコンクリート中に埋 設した ${ }^{4)}$ 。

内部水分の検討として, セラミックセンサの埋設深さはコンクリ 一ト表面より $1 ， 3$ および $5 \mathrm{~cm}$ とし，深さ毎にセラミックセンサ 2 ないし 3 個を図 1 に示寸方法により埋設した。埋設箇所は，実大壁 は左右対に高さ方向は 3 段（上段：CS-上部，中段：CS-中央部，下 段：CS-下部), および横方向は中央部と端部の 2 列とした。また, 小型試験体は試験体中心部を測定部とし，ポータブル型 LCR メータ (サンプリング $1 \mathrm{kHz}$ )を用いて電気抵抗及び静電容量を測定した。 なお, 本研究では, 各埋設箇所における電気抵抗の平均值を用いて 評価を行った。なお，内部水分は埋設したセラミックセンサ（2 個 ないし 3 個）の平均值とした。内部相対湿度の評価を実施するため JIS C2142 付属書に記載されているグリセリン水溶液を用いた調湿 方法によったデシケーター（室温 $20^{\circ} \mathrm{C}$ 環境下）を用意し，電気抵抗 とセラミックセンサの相対湿度の関係を取得し，この関係よりコン クリート中の水分状況について評価を実施した。

\section{(2)表層水分測定方法}

コンクリート表層の水分測定は押当て型「四電極法電気抵抗計 (Wenner 法)」および「電気抵抗式含水率計」を用い，透気性試験 も同位置にて実施した。 


\section{(2) 透気性の試験方法}

原位置透気試験は TPT 法を使用し, 式(1) に示寸演算子を用いて透 気係数を算出した。なお, 模擬壁試験体における透気係数は図 1 に 示寸 6 点の平均值 (以下, $\mathrm{Kt}$-平均) とし, 高さ方向の検討には, $\mathrm{Kt}-$ 上部または Kt-下部の同一測定高さ 3 点の平均值を用いた。

$$
K_{t}=\left(\frac{V_{c}}{A}\right)^{2} \cdot \frac{\mu}{2 \cdot \varepsilon \cdot P_{a}} \cdot\left\{\frac{\ln \frac{P_{a}+\Delta P}{P_{a}-\Delta P}}{\sqrt{t_{f}}-\sqrt{t_{0}}}\right\}^{2}
$$

$$
\text { ここに, }
$$

$$
\begin{aligned}
K_{t}: & \text { 透気係数 } \\
V_{c}: & \text { 内部チャンバーの体積 } \\
A: & \text { 内部チャンバーの断面積 } \\
\mu: & \text { 空気の粘性 } \\
\varepsilon: & \text { 空隙率 }(0.15) \\
P a: & \text { 大気圧 } \\
\Delta P: & \mathrm{t}_{0} \sim \mathrm{t}_{\mathrm{f}} \text { 間の圧力増分 } \\
t_{f}: & \text { 計測の終了時間 } \\
t_{0}: & \text { 計測開始時間 }(60 \text { 秒 })
\end{aligned}
$$$$
\left(\mathrm{m}^{2}\right)
$$$$
\left(m^{3}\right)
$$$$
\left(\mathrm{m}^{2}\right)
$$$$
\left(\mathrm{Ns} / \mathrm{m}^{2}\right)
$$$$
\left(\mathrm{N} / \mathrm{m}^{2}\right)
$$

\section{(3) 細孔構造の試験方法}

細孔構造解析は，水銀圧入法によった。本試験は脱型後からの組 織変化を検証するため, 脱型時及び脱型後 $3,7,14,28$ および 91 日の乾燥日数において, 図 2 に示した位置でサンプルを採取した。 表層部のサンプルは暴露面から $1 \mathrm{~cm}$ の範囲で採取した。内部のサン プルは暴露面から $3.5 \mathrm{~cm}$ 離れた $3 \times 3 \mathrm{~cm}$ のサンプルを対象とした。 管理試験体と小型試験体では試験体形状が異なるため, 乾燥条件の 差異が発生する。湯浅ら ${ }^{7)}$ によれば, 細孔構造に示される総有効細 孔量の変化（水セメント比 $60 \%$, 乾燥開始材齢 7 日) は暴露面から $2.5 \mathrm{~cm}$ の範囲で大きく変化し, $2.5 \mathrm{~cm} \sim 5.0 \mathrm{~cm}$ 以降では概ね一定で あることが示されている。このことにより, 異なる試験体形状によ る細孔構造の不均質性は表層 $2.5 \mathrm{~cm}$ より内部であれば差は小さく, 本研究で採取した管理試験体の表層部及び内部の細孔組織は小型試 験体の細孔組織と同一であると考え評価を行った。

採取したサンプルは 48 時間真空乾燥した後, 水銀圧入法による細 孔構造解析を実施し, 乾燥日数と細孔構造が透気係数に及ぼす影響 について検討を行った。
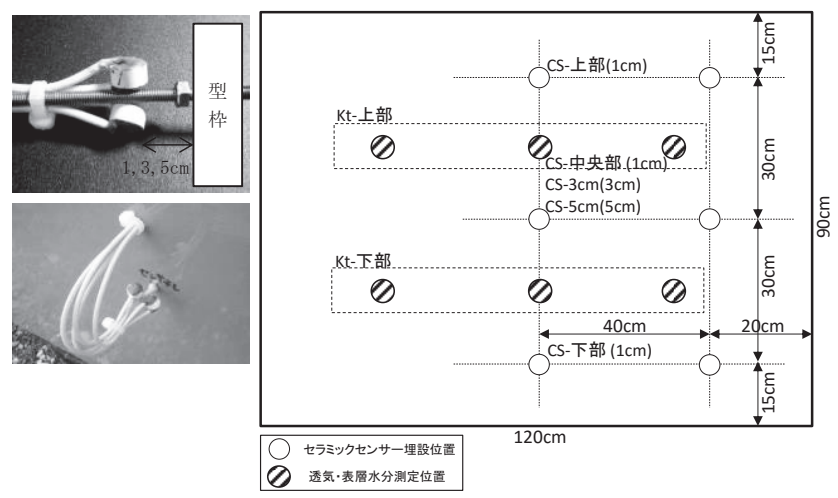

図 1 セラミックセンサの埋設位置及び測定位置

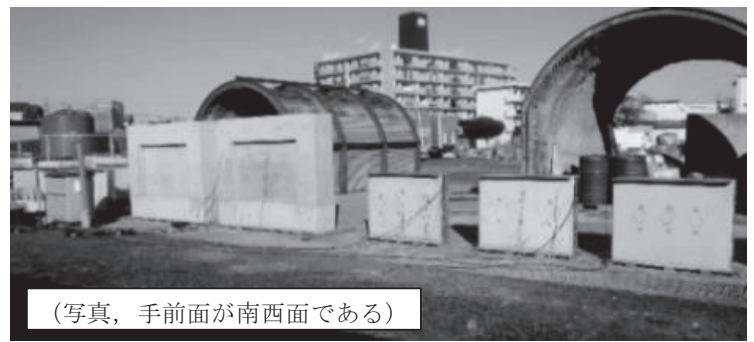

写真 1 屋外環境下に設置した模擬壁

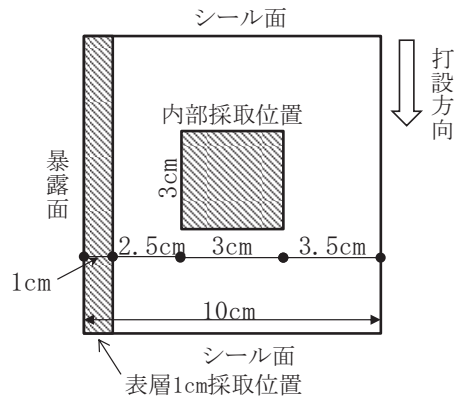

図 2 細孔構造解析サンプル採取位置

\section{3. 試験結果及び考察}

\section{1. セラミックセンサの電気抵抗と相対湿度の関係}

グリセリン水溶液を用いた調湿方法による電気抵抗と相対湿度の 関係を図 3 に示す。

図 3 に示した電気抵抗は，相対湿度 99\%環境下に静置した時の值 を基準としている。

コンクリートの内在水分は, 液滴もしくは気体として存在してい ると考えられている。埋設したセラミックセンサは，常にコンクリ 一ト内の湿度と平衡状態であると仮定して, 本研究では, 古賀ら ${ }^{8)}$ の報告に表記されているコンクリート中の含水率の推定式（式(2)) を相対湿度に修正し定数を定め, コンクリート中の相対湿度を推定 した。

将来的には, 電気抵抗より推定したコンクリート中の相対湿度に 加え，対象とするコンクリートの等温吸着曲線を取得することによ りコンクリート内部の含水率を推定する手法を検討することが課題 と考える。

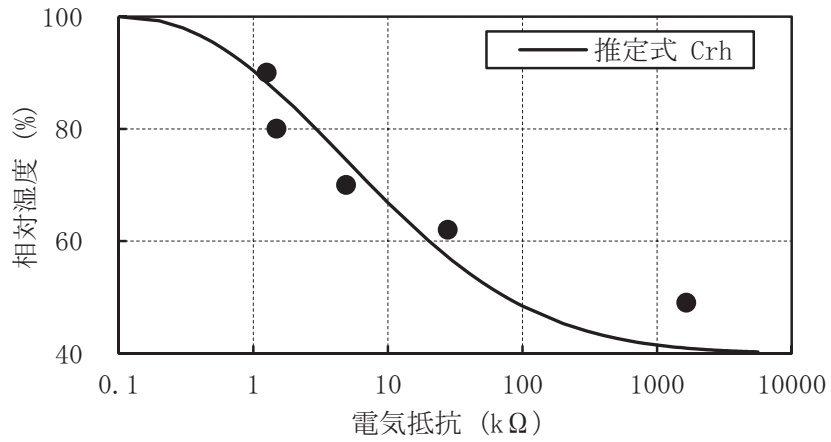

図 3 電気抵抗と質量含水率（相対湿度）の関係 


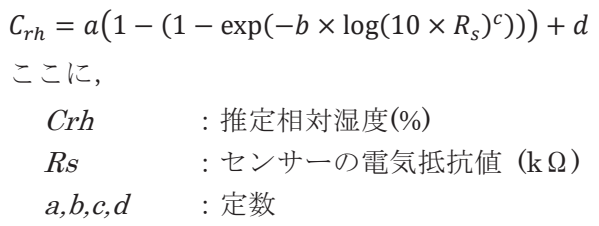

\section{2. 屋内環境下における挙動（小型試験体）}

\section{(1) 表層水分と透気係数}

21-18-20N，21-18-20BB および FB における, 乾燥日数と透気係数 および乾燥日数と表層含水率の関係を図 4 , 電気抵抗率と透気係数 の関係を図 5 に示す。

図 4 に示した乾燥日数と透気係数および乾燥日数と表層含水率の 関係より, 屋内環境ではコンクリートは材齢と共に含水率は低下し, 脱型材齢 3 日の時点で SIA262 が定める透気試験時の含水率 $5.5 \%$ に 達寸ることが認められた。一方，21-18-20N の透気係数は緩やかに 増加し, 脱型時 (透気係数： $0.46 \times 10^{-16} \mathrm{~m}^{2}$ ) に比べ材齢 365 日時点 (透気係数 : $1.5 \times 10^{-16} \mathrm{~m}^{2}$ ) まで緩やかに増加していくことが認めら

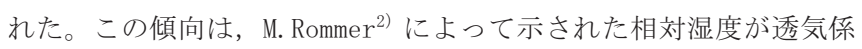
数の経時変化に及ぼす影響と類似していた。

21-18-20BB の透気係数の増加傾向は 21-18-20N と似通っているが, 透気係数の值自体は, 21-18-20N より小さいものであった。これは, 表 1 に示寸材齡 28 日強度が 21-18-20N より高いことと関連している。 FB は若材齢において急激に透気係数が増大し, その後緩やかに増加 する傾向が認められた。この傾向は, 図 5 に示す Wenner 法による電 気抵抗率と透気係数の関係に近いものであった。

Wenner 法は表層 $5 \mathrm{~cm}$ の平均的な水分量を評価すると考える。FB においては水和反応が相対的に緩やかであるため, 表層部が乾燥し たことによって透気係数が急激に増大したと考えられる。これは, 図 7〜9 に示される乾燥日数と相対湿度の関係のように, ごく表層の 埋設深さ CS-1 cm から推定した相対湿度の変化が，21-18-20N に比 べ脱型時より急激である点とも整合している。また, FB の水粉体比 (W/B) は21-18-20N 及び 21-18-20BB より小さいものの, 水セメント 比（W/C）は 71.3\%と 21-18-20N や 21-18-20BB のそれより大きいた め, 図 10〜11 に示寸細孔構造の変化より, 透気性に寄与寸るとされ る細孔径 $0.1 \mu \mathrm{m}$ 以上 ${ }^{9)}$ の細孔容積が他に比べ大きいこととも符合 する。したがって, フライアッシュを用いたコンクリートは普通ポ ルトランドセメント, 高炉スラグ微粉末を用いた場合より, 同一条 件下では表層の組織構造が粗であり, 水分が急激に逸散したことに より透気係数が若材齢時に増大したと考えられる。

図 5 に示寸屋内環境下における電気抵抗率と透気係数の関係にお いて, 両者の関係は脱型時の緻密度によって乾燥速度が異なるが, いずれのコンクリートにおいても電気抵抗率が $20 \mathrm{k} \Omega \mathrm{cm}$ まで透気係 数が急激に変化し $70 \mathrm{k} \Omega \mathrm{cm}$ 付近で透気係数が概ね一定になる傾向が 認められた。図 6 に示寸雨宮ら ${ }^{10)}$ の論文を参考にすると, 電気抵抗 率 $70 \mathrm{k} \Omega \mathrm{cm}$ で透気係数との関係に変曲点を迎えており, この時点の 透気係数によって中性化速度係数の評価が出来ることが示されてい る。このことから, この付近の電気抵抗率の変化と型枠脱型後の材 齢との関係を検討することにより，実用的な透気係数の評価時期の 目安が得られるものと考えられる。

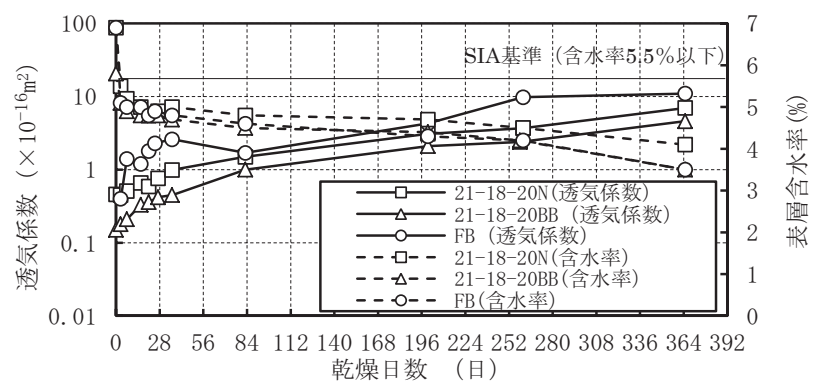

図 4 乾燥日数と透気係数及び表層含水率の関係

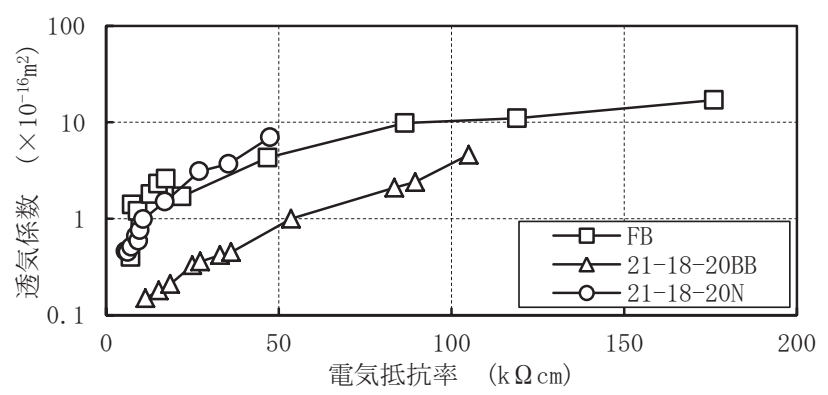

図 5 電気抵抗率と透気係数の関係（屋内環境下）

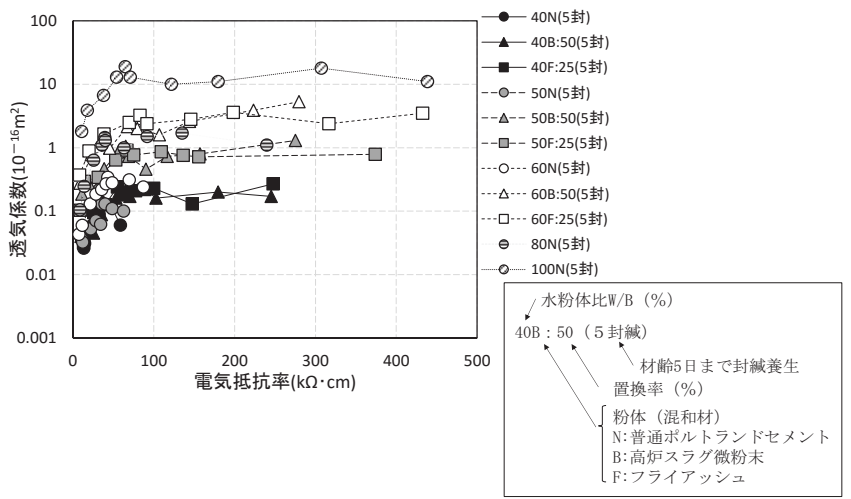

図 6 雨宮らによる電気抵抗率と透気係数の関係 ${ }^{10)}$

\section{（2）内部水分の影響}

乾燥日数とセラミックセンサの電気抵抗から推定した相対湿度の 関係を図 7 9 に示す。深さ $1 \mathrm{~cm}$ に埋設したセラミックセンサはセ メントの種類によらず乾燥日数 28 日間後に相対湿度 $70 \%$ 前後まで 低下した。21-18-20N では埋設深さによって乾燥進行が異なってい るが，21-18-20BB では埋設深さ $3 \mathrm{~cm}$ と $5 \mathrm{~cm}$ での相対湿度は差異な く低下している。一方, FB は埋設深さ $1 \mathrm{~cm}$ と $3 \mathrm{~cm}$ 及び $5 \mathrm{~cm}$ の差 が大きいことから，前述に示した透気係数の急激な増大はこの表層 $1 \mathrm{~cm}$ の領域の影響を受けたためと推定される。

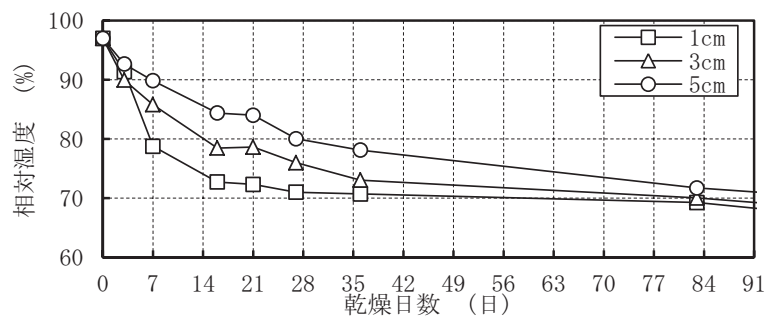

図 7 屋内環境下に静置した湿度変化（21-18-20N） 


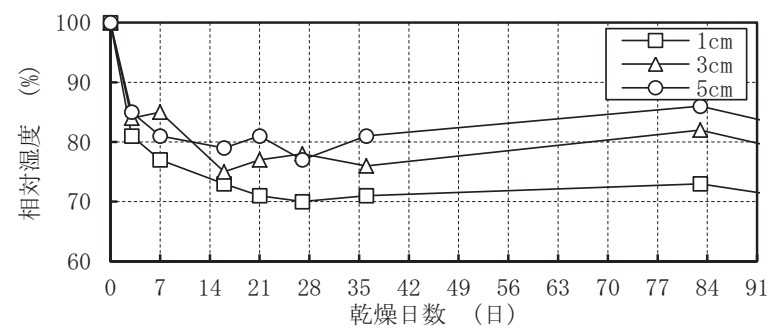

図 8 屋内環境下に静置した湿度変化（21-18-20BB）

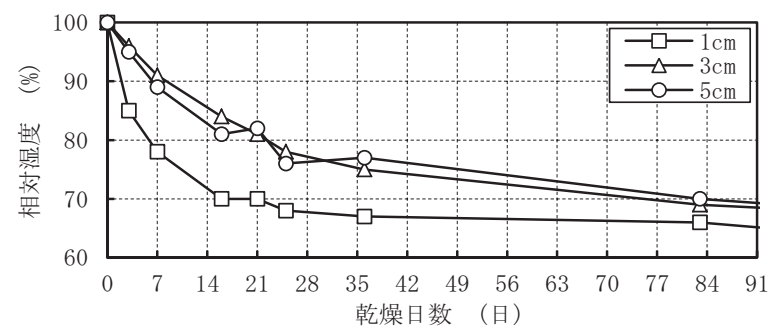

図 9 屋内環境下に静置した湿度変化 (FB)

\section{（3）細孔構造による影響}

表層及び内部における細孔容積と材齢の関係を図 10,11 に示す。

図 10 に示寸表層 $(1 \mathrm{~cm})$ における総細孔容積は，21-18-20N では 脱型時から乾燥日数に関わらず概ね一定であるが, 21-18-20BB およ び FB は脱型時から乾燥日数が進むにつれて総細孔容積の低下が認 められた。細孔組織においては, 強度・収縮・耐久性に寄与寸る細 孔径は異なるとされており, 橋田らによると, 強度に寄与寸る細孔 径は $0.05 \mu \mathrm{m}$ 以上の空隙であり, 透気性・透水性に寄与寸る細孔径 は $0.1 \mu \mathrm{m}$ 以上の粗大組織とされている ${ }^{9)}$ 。ここで $0.1 \mu \mathrm{m}$ 以上の 総細孔容積について図 10 に示寸表層部の細孔構造の変化を見てみ ると, 湯浅ら ${ }^{7)}$ に示されているように表層部の変化は細孔径分布全 域にわたり小さいことを示しており, 寸なわち, 内部とは異なり， コンクリート材齢が経過しても表層の細孔構造の変化（緻密化）が 小さいことと推測される。一方, 図 11 に示寸内部の総細孔容積は材 齢に伴い減少傾向にあった。これは, 図 7〜9に示すコンクリート中 の乾燥日数とセラミックセンサで測定した相対湿度の関係において, セメントの種類によらず，表層 $1 \mathrm{~cm}$ に比べ表層 $3 \mathrm{~cm}$ および $5 \mathrm{~cm}$ の相対湿度が高いことから, 保持されている水分が多く, このこと により, 水和反応が進行し総細孔容積が減少したと考えられる。

したがって, コンクリートの表層部の透気係数の増大は細孔構造 に依存することも考えられるが，相対的に表層の含水率に依存する ものと推測される ${ }^{11)}$ 。また, 乾燥日数 91 日において, 表層・内部 共に細孔径 $0.1 \mu \mathrm{m}$ 以上の総細孔容積が乾燥日数 28 日と変化が認め られないことから, 乾燥日数 28 日以降はこの径に影響する水和も収 束傾向を示寸と考えられる。すなわち，この付近の材齢において透 気係数に影響する因子は, 主としてコンクリートの内在水分の保持 量や逸散性によるものと推測する。

異なるセメントを用いた場合でも, 乾燥初期においては, 細孔構造 及び表層の水分状態が透気性に影響を与えると考えられる。一方、 乾燥日数 28 日以降は水分逸散によって内部まで透気層が形成され たことにより, 乾燥日数 180 日前後まで乾燥に伴い緩やかに透気倸 数が増加したことが推測される。よって, 乾燥日数 28 日以降におい
て表層コンクリートの含水状態を適切に把握できれば, 細孔構造の 変化に大きく依存しないコンクリートの表層透気性を概ね評価でき る可能性があると考えられる。

コンクリートの中性化を評価するためには，促進試験においては 材齢 180 日を待つ必要があるが，内在水分の影響を把握することに より, 透気性の観点から早期の評価も可能になると考える。一例と して, 図 4 に示されるように透気係数が比較的安定する抵抗值を目 安（20〜80 k $\Omega \mathrm{cm} ）$ とすることも考えられ, 適用条件も含めて今後 検討を行いたい。

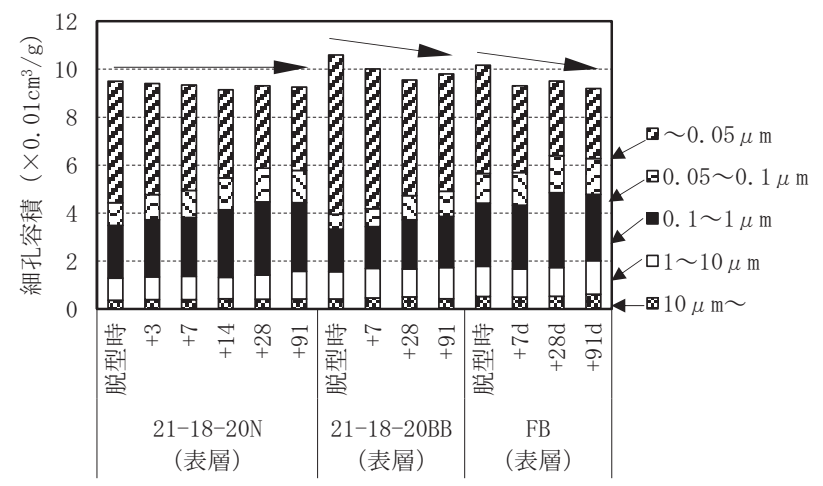

図 10 コンクリート表層 $1 \mathrm{~cm}$ の細孔容積の変化

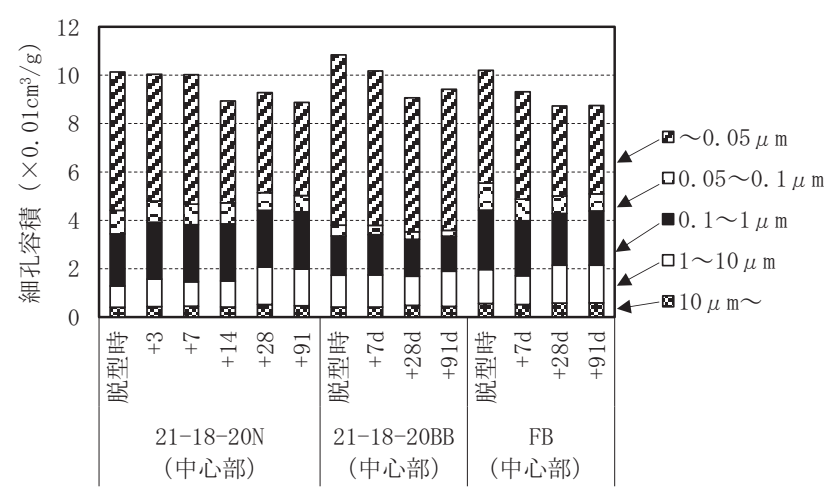

図 11 コンクリート内部の細孔容積の変化

\section{3. 屋外環境下における検討}

\section{(1) 屋外環境下における影響}

屋外環境下における乾燥日数と透気係数および乾燥日数と降水量 の関係を図 12 に, 屋内外における積算温度及び積算湿度の関係を図 13 に示す。

透気係数の経時変化は, 屋内環境下と同様に乾燥日数 28 日頃まで 急激に変化し, 以降は緩やかに増加しており, 屋内と同様の傾向で あった。乾燥日数 28 日までの屋外環境は月平均 $14.1^{\circ} \mathrm{C}$, 最大 $22.8^{\circ} \mathrm{C}$, 最小 $5.8^{\circ} \mathrm{C}$ であり, 屋内環境 $\left(20^{\circ} \mathrm{C}, \mathrm{Rh} 60 \%\right)$ と温度環境に差異が認 められた。また, 屋外における相対湿度は平均 $67 \%$, 最低 $28 \%$ を示し た。そこで, 脱型後の環境変化について, 式(3)に示す日平均気温を 用いた積算值を積算温度とし, 式(4)に示す日平均相対湿度を用いた 積算值を積算相対湿度として定義し評価を行った。その結果, 図 13 に示す屋内外の積算温度及び積算相対湿度の関係より, 積算相対湿 度及び積算温度の両者ともに高い寄与率が認められたが，屋内屋外 の 1 対 1 の対応関係は積算相対湿度の方がより高い傾向を示した。 
このことから, コンクリート構造物の周辺湿度環境を正確に評価し, Wenner 法等による電気的手法を用いてコンクリート表層の含水状 態を把握することによって, 透気性を屋内環境と同様に評価するこ とが可能になるものと考えられる。

また, 降雨の影響について, 乾燥日数 28 日頃までは降雨により一 時的に透気係数が小さくなる傾向を示した。図 14 に示寸同材齢時に 測定した屋内および屋外環境の透気係数の関係が似ていることから， 全体的に降水量の影響が少ないことが考えられる。本研究で対象と する壁面などの鉛直部材では，透気係数に及ぼす降雨の影響は少な く, 降雨の影響は一時的であり, 早川ら ${ }^{12)}$ の研究に示されているよ うに, 一定期間の乾燥を維持することによって, 壁などの鉛直面に おいては屋内同様に屋外環境下の透気係数を評価可能であると考え る。

$$
\begin{aligned}
I_{\text {temp }} & =\sum \text { Temp } \\
I_{R h} & =\sum \frac{1}{R h} \\
\text { ここに, } & \\
I_{\text {temp }}: & \text { 積算温度 }\left({ }^{\circ} \mathrm{C}\right) \\
I_{R h}: & \text { 積算相対湿度 } \\
\text { Temp : } & \text { 平均日気温. } \\
R h: & \text { 日室温 })\left({ }^{\circ} \mathrm{C}\right) \\
R h \text { 平均湿度 } &
\end{aligned}
$$

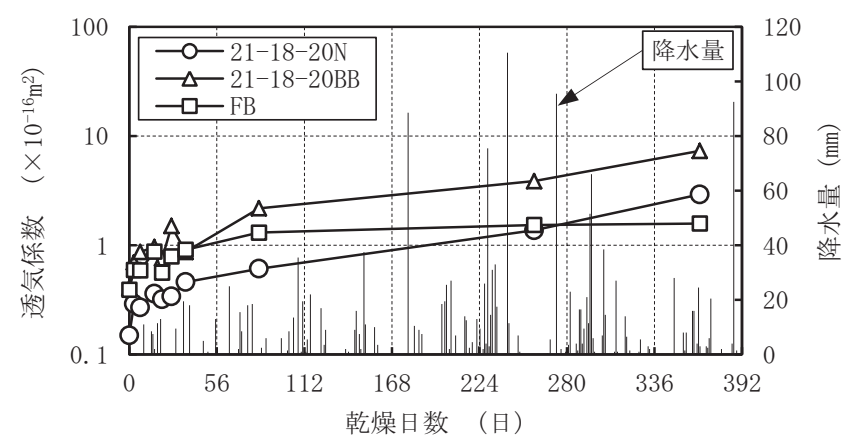

図 12 乾燥日数と透気係数の関係（屋外環境下）

屋内 積算温度 $\left(\Sigma\right.$ temp $\left.\left({ }^{\circ} \mathrm{C}\right)\right)$

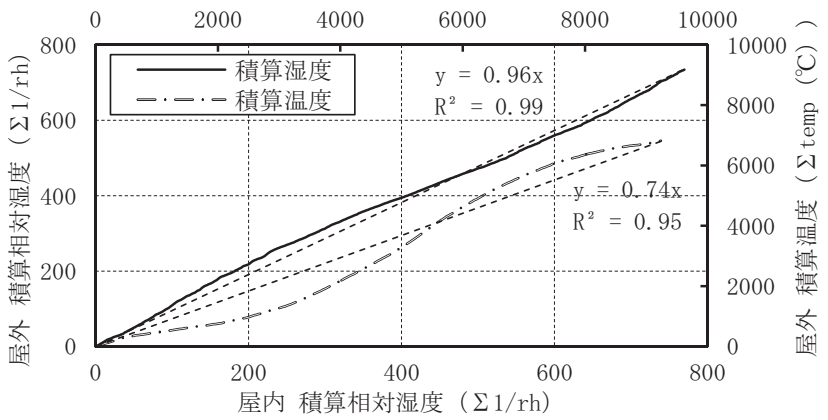

図 13 屋内外環境における積算温度・湿度

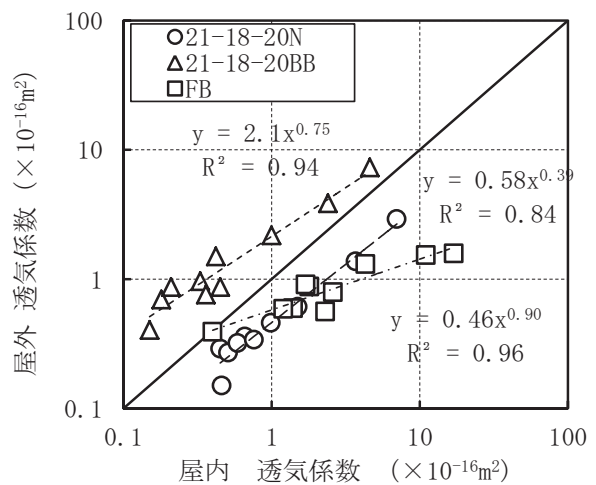

図 14 屋内・屋外暴露環境における相対関係（同材齢時）

図 15 に乾燥日数と電気抵抗率の変化を示す。乾燥日数と電気抵抗 率の関係において, 乾燥日数 28 日頃まで使用材料によって電気抵抗 率の変化に差異が認められた。この傾向は図 12 に示寸透気係数の経 時変化と同様であった。

図 16 に電気抵抗率と透気係数の関係を示す。透気係数と電気抵抗 率の関係では電気抵抗率約 $10 \sim 20 \mathrm{k} \Omega \mathrm{cm}$ 付近に透気係数と電気抵抗 率の関係に変曲点が認められる。この変曲点は雨宮ら ${ }^{10)}$ の研究に おいても認められ，この時点以降の透気係数とコンクリートの中性 化深さの相関が高いことから，前述したように屋外においても，こ のような時期（電気抵抗率 $20 \mathrm{k} \Omega \mathrm{cm}$ 以上）で透気係数の評価を行う ことが一つの目安になるものと考える。

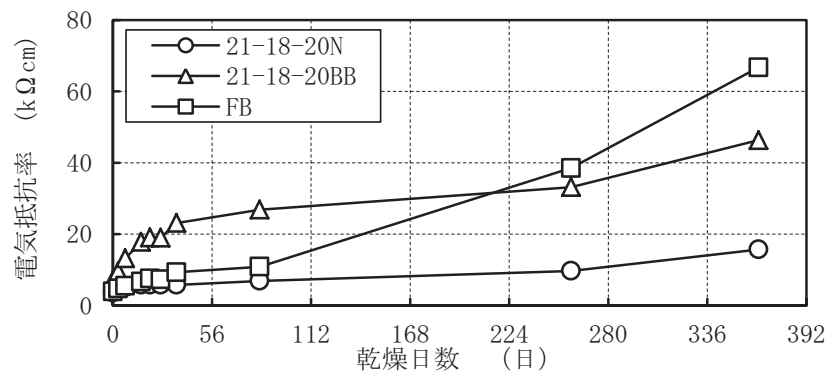

図 15 乾燥日数と電気抵抗率の関係（屋外環境下）

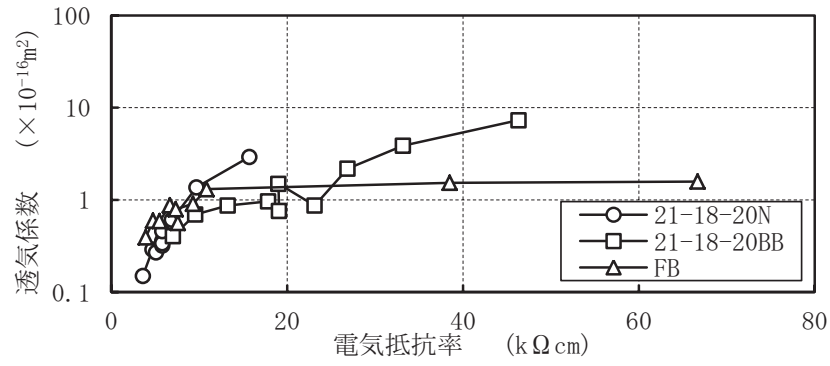

図 16 電気抵抗率と透気係数の関係（屋外環境下）

\section{(2) 部材の深さ及び高さ方向による影響}

21-18-20Nの深さ方向における, セラミックセンサの乾燥日数と 相対湿度及び降水量の関係を図 17 に示寸。また，埋設高さ方向にお ける乾燥日数と透気係数及び相対湿度の傾向を図 18 に示す。

図 17 に示寸深さ方向におけるセラミックセンサの抵抗值と降水 
量では, CS-1 cm は降雨の影響を受け変動し, CS-3 cm は CS-1 cm に比べ相対的に変化が遅かった。また, CS $-5 \mathrm{~cm}$ では降雨の影響は 小さく徐々に乾燥する傾向が認められた。この点は屋内の挙動と類 似している。一方, 透気係数は大きく変動することなく推移してい た。透気試験及び電気抵抗率の測定は, 降雨があった場合その数日 後としており, 降雨による供給水分はコンクリート表層の含水状態 に若干の影響を及ぼすものの, 透気係数一の影響は一時的なもので あると考えられ前述の早川らの知見を裏付ける結果となった。

図 18 に示寸高さ方向による降雨の影響は, 上部 (CS-上部) は降雨 の影響を受け変動するが, 早期に乾燥する傾向を示した。一方下部 は長期にわたって相対湿度が比較的高い傾向を示した。すなわち, 試験体上部は乾燥しやすく, 下部は雨掛りによって湿潤となりやす い環境を形成すると推測する。一方, 透気係数は上部側が下部側に 比べ約 1.5 倍大きくなる傾向を示した。この 1.5 倍の透気係数の差 は, 中性化速度係数と透気係数に関する既往の研究 ${ }^{13)}$ に照らすと, 中性化速度係数としては 1.2 倍であり, 本試験においてはそれほど 大きいものとは考えられないが，「部材の平均的な透気係数の評価」 の観点から考えると, 部材の高さ方向中央付近が試験選定位置候補 に成り得ると考えられる。

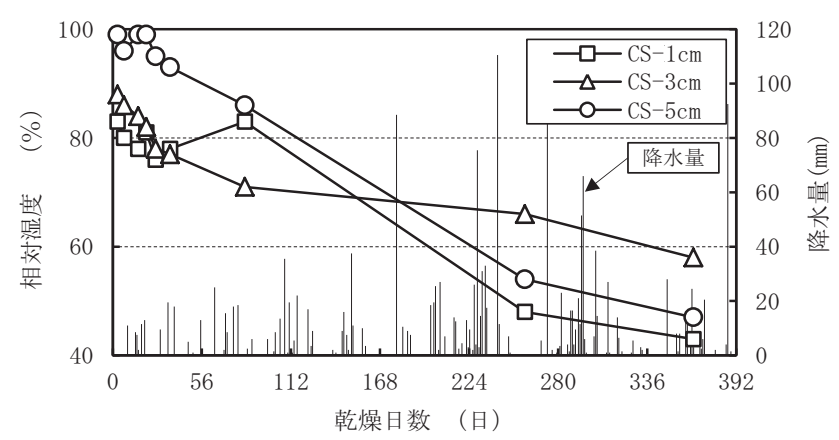

図 17 深さ方向の乾燥日数と相対湿度の関係

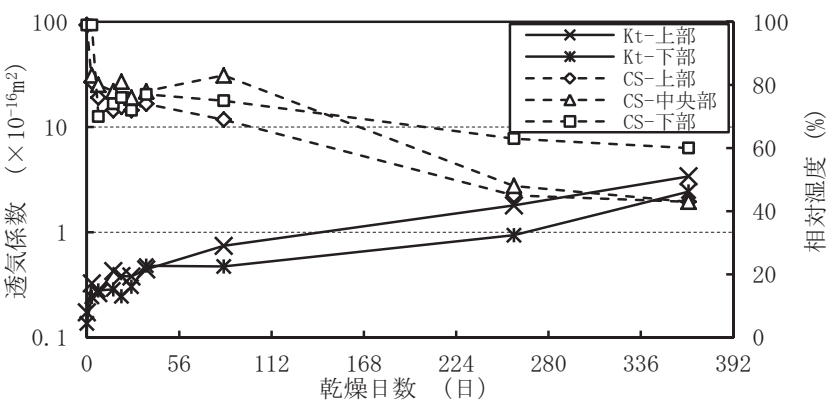

図 18 高さ方向による乾燥日数と透気係数・相対湿度の関係

\section{4. まとめ}

新設におけるコンクリートの水分特性と透気係数について屋内・ 屋外環境下に静置したコンクリートを用いて検討し, 早期の透気性 評価方法の提案に向けた基礎的研究を行った。

本研究で得られた知見を下記に示す。

（1）フライアッシュを用いたコンクリートにおいては，表層 $1 \mathrm{~cm}$ 程度における乾燥が透気性に大きく影響することを細孔径の 検討も踏まえて示した。

（2）内在水分と細孔組織が透気係数に及ぼす影響は, 乾燥日数 28
日を境に異なることが認められた。材齢 28 日以降においては, 主として表層コンクリートにおける含水状態が透気性に対し て支配的になる可能性のあることを示した。

（3）上記のことから，新設コンクリートの表層透気性評価におい ては，特にコンクリートの含水状態の把握が重要であり，一 案として電気抵抗率の評価による手法を提案した。

（4）屋外環境においても，積算湿度の指標などを用いて周辺環境 を適切に評価することによって, 屋内同様に透気性を評価で きる可能性を示した。

（5） 部材の局所（高さ方向）における透気係数の差異は含水状態 に影響するものと考えられ, 部材高さ方向中央部の透気係数 がコンクリートの平均的な品質を表していることを示した。

\section{5. 今後の課題}

本研究では, コンクリート内在水分の水分逸散性による透気係数 の変化について検討したが, 水セメント比によっては水和反応によ る乾燥影響が強く出る可能性があると考えられ，実構造物では透水 型枠等の使用の有無，剥離剤の塗布量及び種類によってコンクリー トの表面状態が異なり，乾燥速度や透気性に影響を及ぼす可能性が あると考えられる。

今後は，水和反応による乾燥や表層（表面）の改質が透気性に及 ぼす影響について更なる検討を行いたい。

\section{参考文献}

1）蔵重 勲，廣永 道彦：脱型材齢や暴露環境がコンクリートの強度特性や 表層透気性ならびに中性化抵抗性に及ぼす影響の実験的評価，コンクリ 一ト工学年次論文集, Vol. 32, No. 1, pp. 623-628, 2010.6

2) M. Rommer: Effect of moisture and concrete composition on the Torrent permeability measurement, Materials and structures, vol. 38, pp. 541-547, 2005.6

3) F. Jacobs, R. Torrent: Swiss standards SIA 262:2003, a step towards performance-based specifications for durability, Concrete in aggressive aqueous environments - Performance, Testing, and Modeling, pp. 532-539, 2009.6

4）湯浅 昇，笠井 芳夫，松井 勇：埋め込みセラミックセンサの電気的特性 によるコンクリートの含水率測定方法の提案, 日本建築学会構造系論文 集, No. 498, pp. 13-20, 1997.8

5) R, Torrent: A two-chamber vacuum cell for measuring the coefficient of permeability to air of the concrete cover on site, Materials \& Structures, vol. 25 , no. 150 , pp. 358-365, 1992.7

6）国土交通省気象庁： http://www. jma. go. jp/jma/index. html（参照 2016. 1. 12)

7）湯浅 昇，笠井 芳夫，松井 勇：乾燥を受けたコンクリートの表層から内 部にわたる含水率, 細孔構造の不均質性, 日本建築学会構造系論文集, No. 509 , pp. $9-16,1998.7$

8）古賀裕久, 渡辺 博志: 屋外に暴露したコンクリートの含水率モニタリ ング結果，コンクリート工学年次論文集, Vol. 28, pp. 641-646, 2006.6

9）橋田 浩: 細孔空隙構造からのコンクリートの各種特性と形成機構に関す る検討，清水建設研究報告，第 63 号，1996.4

10）雨宮 染，今本 啓一，清原 千鶴，桝田 佳寛，棚野 博之，親本 俊憲, 陣内 浩: 混合セメントを用いたコンクリートの中性化と透気係数に関す る研究，日本建築学会関東支部研究報告集，Vol. 85, pp. 173-176, 2015.3

11）蔵重 勲, 山田一夫，小川 彰一: 非破壊透気試験等を用いたコンクリー 卜品質管理の可能性検討一指定廃棄物の最終処分に向けて一, セメン ト・コンクリート論文集，Vol. 69 No. 1 pp. 287-294， 2015

12）早川健司, 水上 翔太, 加藤 佳孝: 表層透気試験による構造体かぶりコン クリートの品質評価に関する基礎的研究, 土木学会論文集 E2（材料・コ ンクリート構造), Vol. 68 , No. 4, pp385-398, 2012.12

13）田中 章夫, 今本 啓一: 表層透気性による既存 $\mathrm{RC}$ 構造物の中性化予測に 関寸る研究，日本建築学会構造系論文集，No. 691，pp. 1539-1545，2013.9 


\title{
RELATIONSHIP BETWEEN SURFACE AIR PERMEABILITY AND MOISTURE BEHAVIOR OF NEWLY CONSTRUCTED CONCRETE MEMBERS
}

\author{
Akio TANAKA ${ }^{* 1}$, Kei-ichi IMAMOTO ${ }^{* 2}$ and Chizuru KIYOHARA*3 \\ ${ }^{* 1}$ Hachiyo Consultant Corporation, Technical Center, M.Eng. \\ ${ }^{*}$ Prof., Faculty of Engineering, Tokyo University of Science, Dr.Eng. \\ ${ }^{*}$ Research Assistant, Faculty of Engineering, Tokyo University of Science, Dr.Eng.
}

Surface-layer air permeability depends strongly on the water content of concrete. Therefore, newly built structures, which contain a large amount of water, require water content evaluation during inspections. The relationships among the material age, surface-layer air permeability, relative humidity, and air permeability coefficient of newly cast concrete have been reported, but there have been few studies on the relationship between the water content and air permeability of young concrete. In this study, the effects of the water content of young concrete on surface-layer air permeability were investigated to propose a method for evaluating the durability of newly built concrete structures. To study the relationship between water behavior and air permeability in concrete in indoor and outdoor environments, specimens and actual-size walls containing embedded ceramic sensors were produced from ordinary Portland cement, Portland blast furnace cement type B, and fly ash cement. The relationships among the water content of concrete, Wenner method resistivity, and air permeability were determined. In addition, pore structure was analyzed by the mercury intrusion technique and discussed. The effects of the relationship between pore structure and water content on air permeability varied according to material age for different kinds of cement in an indoor environment. The results indicated that it is possible to evaluate the durability of concrete aged 28 days or older, for which the effects of structural changes can be removed. 